\title{
On the Segmental-Structural Formation of Syllable Models (on the Material of the Spanish Language)
}

\author{
Aliyeva Sabina Khagani ${ }^{1}$ \\ ${ }^{1}$ Department of English Grammar, Azerbaijan University of Languages, Baku, Azerbaijan \\ Correspondence: Aliyeva Sabina Khagani, Department of English Grammar of Azerbaijan University of \\ Languages. Baku, Azerbaijan. Tel: 994-050-531-1599. E-mail: shalalahaliyevah@yahoo.com or \\ shalalahaliyevah@gmail.com
}

Received: July 6, 2016 Accepted: July 30, 2016 Online Published: September 23, 2016

doi:10.5539/ijel.v6n5p139 URL: http://dx.doi.org/10.5539/ijel.v6n5p139

\begin{abstract}
The article is dedicated to study of syllable - a segmental language unit. In the article it is noted that status of the syllable is subject of dispute. A syllable is a segmental unit formed by phonemes (vowel and consonant) based on intrasystemic rules of a certain language in syntagmatics. It is indicated that phonotactics studies syntagmatic relations of phoneme in speech act. The article clarifies concepts like phonetic and phonological. Phonetic characteristics of syllable are that it is the minimal pronunciation unit and minimal perception tool. Phonological syllable is closely related to investigation of rules of phonotactics in a certain language. Some syllable models in Spanish are defined with given examples in the article.
\end{abstract}

Keywords: syntagmatics, combinatory, paradigmatic, phonologic system, syllable

\section{Introduction}

All the languages are divided into syllables during speech act. The paradoxical case for this unit is that the people who speak that language (native speakers) accept the syllabizing natural, and though they master it during the childhood time, against the background of the richness of practical knowledge, they face serious difficulties in the matter of division into syllables, and this matter remains unsolved.

\section{Research Methodology}

We have used in this article descriptive, linguistic-analysis methods in the investigation of syllabic structure of words, in the monosyllabic and polysyllabic words in the Spanish language. Descriptive method helped us to describe the existing variants of the division of morphemes and words by means of examples from the Spanish language. By means of the linguistic-analysis method we tried to analyze the syllable phenomenon of the Spanish language from the linguistic point of view.

\section{Scope of the Study}

Status of the syllable draws attention with its indefinite nature among other segmental units of language terms of phonological theory. Despite the fact that in linguistic sources the investigation of the syllable, "the smallest pronunciation unit" as it was defined by Zinder (Зиндер, 1979, p. 251), has an old history, the matter of its status and boundary is still remaining as a subject of dispute. Zinder, who said that physiological factors should be taken into consideration in connection with the matter of the formation of syllables and noted that "for all the languages there is not a common factor which can condition the division of the speech into syllables" (Зиндер (Zinder), 1979, p. 256)

As K. Pike notes, "the ambiguity" of the investigation status of the syllable items from its imprecise function as a language unit. For instance, descriptivist deny the concept of syllable, as it is simpler to present morpheme as a sequence of phonemes without addressing the syllable as an intermediate unit (Pike, 1979, p. 48).

In the languages with syllabic structure (most of the languages of the world belong to this language structure) a syllable can contain two morphemes or a morpheme can contain two syllables. In the languages of this type syllable and syllabification is not related to the meaning, and according to Zinder "the syllable does not act as a phonological unit” (Зиндер (Zinder), 1979, p. 251). For example,

(bıț ț̣̣ə), (ræậạiš), “escribió” (es-kri-bjó), “viuda” (bjú-đa), 
"cuadro" (kwá-đro), "ruego" (r: wé-ḡo), "antiguo" (an-tí-wo).

Maslov who describes sonority and muscle tension theories notes that "syllable structure of utterance is based on the substitution of the increasing and decreasing moments of the muscle tension together with sonority of syllable structure. By this, the syllable performs an important function in connection with the sound matter of a language." (Маслов (Maslov), 1998, pp. 67-68).

Potapova notes that "In a language and speech, the functioning of a unit such as a syllable made linguists, acousticians and the specialists of other fields determine the nature of this phenomenon, fully describe the syllable inventory of this or another language, determine the criteria of division into syllables and other efforts. In special literature the matter of the borderline of syllable and the division into syllables is looked through in connection with the problem of syllable formation" (Потапова (Роtapova), 1986, p. 10).

The possibility of the "description of syllable from the viewpoints of phonotactics, perception and acoustics differently" (Потапова (Potapova), 1981, p. 8) is noted by Potapov, and according to his deductions, "as the syllable has poly-functional character, it makes the basis of speech-language hierarchy, and it is the specific minimal unit of the formation of speech and its perception" (Потапова (Potapova), 1981, pp. 6-7).

So, in any language in the study of syllable, it is necessary to address the language speakers' language consciousness, and also to pay attention to the revelation of informative features in the communication process from the point of view of native speakers.

Notable Germanist Gordina also characterizes syllable as "an indivisible speech section, the minimal line of which is indivisible in articulator setting" (Гордина (Gordina), 1973, p. 113).

Yadigar (Veysəlli, 1993) writes about paradigmatic and syntagmatic relations of language units (phonemes): "Whilst the encounter of the units in paradigmatics occurs according to the same differential characteristics, in syntagmatics interrelation extends the opposition range in terms of variation, and along with differential characteristics, integral characteristics are also included here" (Yadigar, 1993, pp. 96-97).

Investigation of phonological units in the organization of word structure stimulated development of a new aspect of phonology - phonotactics. Phonotactics deals with syntagmatic relations of phonemes in speech act. In speech act there are certain patterns of the combinations of phonemes within a syllable. To define combinatory relations between phonemes in the system, three main factors should be considered: the relation of a phoneme to other phonemes, realization sequence of consonants, and finally, identification of phonemic composition within a syllable. As a general matter, these regulations bear fundamental significance for phonotactics, nevertheless they may change depending on certain investigation methods. Studying position for each phoneme in the description of combinations of phonemes and the environment in which the phoneme is realized, i.e., its reciprocal relations with other phonemes is also one of the important factors.

Speech represents continuum of phonemes. Phonemic analysis of the language primarily requires defining its phonemic inventory and its variations that appear in syntagmatics.

As Trubetzkoy notes, "combination of phonemes obeys the rules and laws that are important for the given language and are defined individually for each language" (Трубецкой (Trubetzkoy), 1960, p. 279). One of the principally important aspects of phonology is also to discover "the characteristics that are the same for all of its variants and the characteristics that differentiate it from all of the other phonemes" (Трубецкой (Trubetzkoy), 1960, p. 73).

Benveniste also dealt with the scientific importance of studying phoneme combinations in syntagmatics: "Every discourse in the language is made up of elements capable of multiple combinations and it is this capability that creates uniqueness of human language by means of which we communicate with one-another. Deeper linguistic studies show that meaningful units-morphemes are divided into phonemes which don't have their own meaning and act only as pronunciation units, various combinations of which create meaningful units of language. These "empty" phonemes organized in the system form the basis of any language." (Бенвенист (Benveniste), 1974, p. $102)$.

Solntsev also mentions about the significance of investigating combinatory features: “...combination is one of the general and essential features stipulated by fundamental general characteristics of the system like discreteness and distinctiveness of language units. (Солнцев (Solntsev), 1977, p. 268).

Veysalli expresses his opinion on this topic as follows: "Combinatory analysis which is referred to as distributive in the modern linguistics is also utterly significant for phonological typology, since combination obeys certain rules peculiar to every language" (Вейсалли (Veysalli), 1980, p. 100). 
Babayev writes that in modern linguistics in phonological investigations the matter of phoneme combinations occupies the central place. According to the author, "it is impossible to imagine the sound structure of any language fully without taking into consideration syntagmatic characteristics of phonemes". (Бабаев (Babayev), 2011).

It is not possible to explain phonemic distribution of one language with the facts of another language. In other words, each language should be described based on its own architectonics. Distributive characteristics discovered for one language can be compared to those characteristics of another language. Hence, similar and distinctive features of compared languages can be determined. This kind of approach to studying languages facilitates teaching process of a foreign language as well.

According to Veysalli, "combinations that are not common in native language make difficult to learn foreign language" (Вейсалли (Veysalli), 1980).

It should be added that in descriptive linguistics close attention have been paid to studying language units and the distribution of their variants in relation with each-other in speech act.

According to Voronkova, who analyzed the approaches of desriptivists to distribution characteristics of phonological units, "in classification and description of phonemes and their variants the meaning aspect is less significant than sequence aspect" (Воронкова (Voronkova), 1981, p. 86). Investigation of relations of phonological units within a system is directly related to their realization in speech act.

Dichotomic theory of Jakobson should be particularly noted in this respect (Jakobson, 1971-1985). According to this theory, features of phoneme have binary characteristics and they can be described based on binary. According to Murashkina, the investigation of the relations of phonological units is exceptionally connected with the distribution features of their realization in speech. (Мурашкина (Murashkina), 2014).

A syllable is a combination of segmental and suprasegmental units that create the smallest structure and is in action during speech act, it has certain objective characteristics and is divided in perception of speech act. While one of the objectives of the syllable is it being the realization position of the stress, it's another, and not less important objective is to act as elementary distribution models of phonemes in speech act (in syntagmatics). In every language in syntagmatics there are certain intrasystemic limitations in combinations of phonemes. It might be considered that these limitations concern only phonemes, i.e., /x/ phoneme can create a combination with /y/ phoneme or vice versa. However, a second case is possible here, for example, the limitation in phoneme combinations does not cover all the speech chain, and it is related to a certain word structure (beginning, middle and end). Syllable acts as a segment unit in speech flow.

It is a more common practice to address phonemic distribution in determining boundaries of the syllable. In other words, some authors refer to distributive function of the syllable. During consonants' combination within a syllable their distribution on adjacent syllables is done as follows: the combinations that are realized at the end of the previous syllable and at the beginning of the last syllable should coincide with the combinations that are possible in the beginning of the word (phonetic). In case this is not possible, according to phonotactic rules, the superiority is given to the previous syllable on account of the last syllable. So that from informative and functional point, the beginning of the word and syllable is considered to be more important compared to the end, thus, it is more common to find deviance of phonotactic rules in the end of the word rather than in the beginning.

According to Shevchenko, who characterizes the phonotactics as a science about the creation of syllables in the chain of speech, "syllable, as a phonological unit, is a minimal group in which a vowel and a consonant join allowed by a language structure". (Шевченко (Shevchenko), 2011). According to the author, "open syllable $(\mathrm{C}+\mathrm{V})$ is the main syllable structure for all languages". (Шевченко (Shevchenko), 2011). Akhundova in her investigation defines the syllable as "the smallest speech/pronunciation unit whose components are maximum closely connected with each-other”. (Ахундова (Akhundova), 2013).

In cases different variants of syllable combinations at the beginning and end are equally possible, the-CV model that can provide the simplest completion is chosen. For instance, in syllabification of Russian word "sestra" Pulgram gives preference to the sequence /se-stra/. (Pulgram, 1970). The Spanish word "Transcribir" should be divided into the syllables /trans-cri-bir/, but the consonant combination /ns/ at the end of the first syllable is not represented as the consonant combination /scr/ in Spanish. Finally, if the impossibility of variant choice depends on unacceptability of the last vowel to which the last intervocal consonant reached, then the boundary passes between the consonant. (Pulgram, 1970, p. 40). For example, (bıṭ̂ț̣̣), (ræḍ’ ’̣iš).

Pulgram completely rejects the idea that the syllable has any particular function. According to the author, "syllable exists only for its own boundaries" (Pulgram, 1970, p. 40). Presumably, this approach would be valid if 
the main function of syllable was creating a rhythm, speech act was to become rhythmic and it was to be realized through division of speech into syllables.

In modern linguistics phonetic and phonological syllables are distinguished. Phonetic characteristic of the syllable is a universal feature belonging to most of the languages. A phonetic characteristic of syllable is it being minimal pronunciation unit and minimal perception tool. Phonological syllable, on the other hand, is closely related to investigation of rules of phonotactics. Phonological approach to syllable considers combination rules of phonemes and the way they are following one-another with a certain sequence at the beginning and end within a syllable. Distribution limitations and strengthening of separate sounds in certain positions, dependence of the position of stress on the number of components within the syllable are regarded as phonetic characteristics of the syllable. However, as these features are governed with systems of certain languages, they don't bear a universal essence.

There are some points that should not be forgotten while reviewing distributive interpretation of the nature of syllable. First of all, distributive role of the syllable should be understood as a recursiveness of phoneme combination rules. Hence, on certain points of the speech chain these rules cease to act, more precisely, they start to move again. Secondly, in relation to morpheme and word, there are some regularities of phoneme distribution. In this approach we have to accept independent existence of the syllable, as we are not describing the syllable with the help of phoneme distribution, but phoneme distribution with the help of syllable. In this case, distributive function turns into one of the functions of the syllable.

Can we talk about functions which belong to the syllable, and at the same time do not depend on phonotactics? The answer to this question is related to the concept of coarticulation. In phonetic literature, it is shown that in most languages coarticulation rules exist in segmental succession of word structure, and syllable is realized not as a succession of sound composition, but as whole articulatory complex. Coarticulation is linked with mutual influence of phonemes in the speech chain. Coarticulation stipulates the change of phonetic quality of allophones under the phonetic influence of phonemes. Now that coarticulation effect cannot involve indefinite phoneme sequences, the segments where articulation takes place should be defined. We consider that the syllable is such a segmental unit. Accepting the syllable in this quality leads to the following conclusions:

a) syllables are defined not depending on phoneme distribution and at the same time, it's an area where distributive limitations of phoneme are realized, then we find an independent function of syllable-coarticulation;

b) accepting coarticulation as an independent function of the syllable leads to the conclusion that the syllable is a phonetic unit, because coarticulation is of a phonetic essence.

Kasevich explaining the essence of syllable has quite a different approach to it. He attributes language units to inventories - which belong to paradigmatics (system) of a language, and to those which belong to syntagmatics - schemes, and the creation types of non-inventories, those which reflect the rules in an abstract way, for instance, the syllables to syntagmatics (Касевич (Kasevich), 1983). The reality of rules affirms itself with the coincidence of the syllable division regulations in different languages. Kasevich, who investigates the functions of syllable, and coarticulation, which is connected with syllable, notes that "coarticulation phenomenon is connected with mutual influence of phonemes in speech chain. Coarticulation notion demands mutual phonetic influence of phonemes ... because coarticulation effect cannot cover the indefinite phoneme succession. Some scholars claim that syllable is such kind of unit (Касевич (Kasevich), 1983, p. 102).”

But it should be noted that, recent experimental-phonetic investigations show that coarticulation is not limited with a traditional syllable field and can cover much longer phonological chains.

It is difficult to accept syllable as a first class unit (phoneme, morpheme, lexeme, etc.), because it is not possible to talk about syllables that belong to language system (paradigmatics). However, if we assume that in different languages the syllable has different regularities, then we have to admit the reality of syllable structures and their types. Therefore, the syllable belongs to second class of language units, more precisely to syntagmatics.

We would like to note that in Spanish, as in all languages, vowel is a leading component. Vowels can be realized in different positions of the syllable - at the beginning, at the middle and at the end. For instance,

"esto" (és-to), “costumbre” (kos-túm-bre).

Furthermore, vowels can act as an independent morpheme or a word. Vowels can separately represent a syllable. For example,

“día” (dí-a), "ojo" (ó-xo), "ala” (á-la) and so on. 
Unlike vowels, consonant phonemes do not form a syllable and are not the main component of a syllable. In Spanish no syllable can be formed without the presence of vowel phonemes. The number of syllables within a word is proportionate with the number of vowel phonemes (when two or more vowels unite during speech act, the number of syllables reduces).

In Spanish the following syllable types are formed from division of morphemes and words:

1) Pure and open syllables. Vowels use single consonants following and form a syllable by joining them to following vowel, for example,

"época" (é-po-ka);

2) uncovered-closed, covered-closed syllables. These models of syllables are formed based on distribution of two consonants at an intervocal position to the first and second syllable, for example, "immortal" (im-mor-tal), "subversión"(sub-ber-sión);

3) covered-closed and covered-open syllables. These models of syllables are usually formed based on distribution of two consonants at an intervocal position to separate syllables (if the last consonants are not indivisible), for example,

"marzo" (már-zo), "pista” (pís-ta), "alto; (ál-to);

4) covered-open syllable model. When indivisible consonants are present in the word structure, the boundary of the syllable is positioned before them. For example, (pr), (br), (fr), (tr), (dr), (sr), (gr), (pl), (bl), (fr), (kl), (gl). Within a word the boundary of the syllable falls before them, for example,

“copla" (kó-pla), "abrigo" (a-bri-go),

"mezcla" (méø-kla), "perplejo" (per-plé-xo);

5) covered-closed, covered-open syllables. In this syllable model syllable boundary in three-consonant phoneme group falls in the position following the consonant $/ \mathrm{s} /$. For example,

(s) "perspectiva” (pers-pek-tí-ba), “constitución” (kons-ti-tu-øión), etc.

6) uncovered-closed and pure syllable. These models of syllables are formed as a result of distribution of vowel phonemes into separate syllables in the word structure. Strong vowels in Spanish /a/, /e/, /o/ are divided into different syllables, for example,

"aldea" (al-dé- a), "poeta" (po-é -ta), "paseo" (pa-sé-o).

7) When weak vowels in Spanish like (i), (u) are within one syllable, they lose their quality of vowel and are replaced with consonants. For instance, (j) and (w).

"Europa” (ew-ró-pa), "cuadro" (kwá-đro), "viuda” (bjú-đa), "fuí” (fwí),

“apaciguáis” (a-pa-øi-gwájs), "escribió” (es-kri-bjó), “viaje” (bjá-xe), “hay” (aj),

"continuéis" (kon-ti-nwéjs), "ruego" (r: wé-ḡo), "vaciáis" (ba-øjájs), "veis” (bejs),

antiguo"(an-tí-wo), cambiés (kam-bjéjs), "pausa" (páw-sa), "hoy” (oj), "bien” (bien), etc..

There are two types of phoneme combinations in compound words:

a) Combination of the last consonant with the first vowel, for instance,

"encadenamiento";

b) Combination of the last and first vowels, for example,

"sinalefa".

\section{Summary and Concluding Remarks}

According to the conducted research, it could be concluded that CV model is more commonly spread among syllable models. In structures of the analyzed words the only trend in combination of consonants is the fact that the components that are involved in combination are contrasted.

In Spanish the following syllable types exist: pure and open syllables, uncovered-closed, covered-closed syllables, covered-closed and covered-open syllables, covered-open syllable models, covered-closed, covered-open syllables, uncovered-closed and pure syllables.

Besides, weak vowels in Spanish within one syllable may lose their quality of vowel and are replaced with consonants. 


\section{References}

Ахундова, К. Б. (2013). Фонетическая структура начала и конца слова в современном русском и азербайджанском языках. Автореф. дис. док. философии по филол. наукам. Баку: 24 с. (Akhundova, K. B. (2013). Phonetic structure of the beginning and the end of words in modern Russian and Azerbaijani. Synopsis of the dissertation for getting PhD. Baku. p. 24).

Бабаев, Дж. М. (2011). О соотношении вокализма и консонантизма (на материале азербайджанского и русского языков). Русский язык и литература в Азербайджане. Баку: ВСУ, №4, с. 4-6. (Babayev, J. М. (2011). On the correlation of vocalism and consonantism (On the materials of theAzerbaijani and Russian languages). Russian language and literature in Azerbaijan, 4, 4-6. Baku: BSU).

Бенвенист, Э. (1974). Общая лингвистика. Москва. Прогресс. (Benveniste, Е. (1974). General linguistics. Moscow, Progress).

Вейсалли, (Вейсалов) Ф. (1980). Вариативность гласных фонем современного немецкого языка (экспериментальные данные и теоретические проблемы). Автореф. дис. докт. филол. наук. Ленинград, 35 стр. (Veysalli, (Veysalov) F. (1980). Variation of vowel phonemes of modern German language (experimental data and theoretical problems). Synopsis of the dissertation for getting $\mathrm{PhD}$. Leningrad. p. 35)

Воронкова, Г. В. (1981). Проблемы фонологии. Ленинград, Изд-во ЛГУ. 131 стр. (Voronkova, G. В. (1981). Problems of Phonology. Leningrad, Publishing house of LSU. p. 131).

Солнцев, В. М. (1977). Язык как системно-структурное образование. Москва. Прогресс. (Solntsev, В. М. (1977). Language as a systematic-structural formation. Moscow, Progress).

Jakobson, R. (1971-1985). Selected Writings (Ed. Stephen Rudy) (in six volumes): Volume I. Phonological Studies. The Hague, Paris: Mouton.

Касевич, В. Б. (1983). Фонологические проблемы общего и восточного языкознания. Москва. Высщая школа, 295 стр. (Kasevich, V. В. (1983). Phonological problems of general and western linguistics. Moscow. Visshaya shkola, p. 295).

Маслов, Ю. С. (1998). Введение в языкознание. Москва. Высщая школа, 272 стр. (Maslov, Y. S. (1998). Introduction to linguistics. Moscow. Visshaya shkola. p. 272).

Мурашкина, О.В. (2014). Проблема релевантности в фонологической характеристике испанских согласных (Электронный ресурс) Язык и текст. №3. Retrieved from http://langpsy.ru/journal/2014/2/Murashkina.phtml (Murashkina, O. V. (2014). The problem of relevance in the phonological characteristics of Spanish consonants (Electron resourse)).

Pike, K. L. (1979). Universals and Phonetic Hierarchy. Proceedings of the 9th International Congress of Phonetic Sciences, 2. Copenhagen.

Pulgram, E. (1970). Syllable, Word, Nexus, Cursus. The Hague-Paris: Mouton.

Гордина, М. В. (1973). Фонетика французского языка. Ленинград, Издательство Ленинградского университете. 210 стр. (Gordina, М. В. (1973). Phonetics of the French language. Leningrad, Publishing house of Leningrad University. p. 210).

Зиндер, Л. Р. (1979). Общая фонетика. Москва. Высщая школа, 312 стр. (Zinder, L. R. (1979). General phonetics. Moscow. Visshaya shkola. p. 312)

Потапова, Р. К. (1981). Сегментно-структурная организация речи (экспериментально-фонетическое исследование): Автореф. дис. ... д-ра филол. наук. Ленинград, 46 стр. (Potapova, R. K. (1981). Segmental-structural organization of speech (experimental-phonetic investigation). Synopsis of the dissertation for getting PhD. Leningrad, p. 46).

Потапова, Р. К. (1986). Слоговая фонетика германских языков. Москва. Высщая школа, 144 стр. (Potapova, R. K. (1986). Syllabic phonetics of Germanic languages. Moscow. Visshaya shkola. p. 144).

Трубецкой, Н. С. (1960). Основы фонологии. Москва. Высщая школа. (Trubetzkoy, N. S. (1960). Basis of phonology. Moscow. Visshaya shkola).

Шевченко, Т. И. (2011). Фонетика и фонология английского языка. Курс теоретической фонетики английского языка для бакалавров. Дубна: Феникс, 256 с. (Shevchenco, Т. I. (2011). Phonetics and Phonology of the English language. Course of theoretical phonetics of the English language for BD 
students. Dubna, Phoenix, p. 256).

Yadigar, F. (Veysəlli). (1993). Fonetika və fonologiya məsələləri. Bakı. (Yadigar, F. (Veysalli). (1993). Phonetics and phonology problems. Baku).

\section{Copyrights}

Copyright for this article is retained by the author(s), with first publication rights granted to the journal.

This is an open-access article distributed under the terms and conditions of the Creative Commons Attribution license (http://creativecommons.org/licenses/by/4.0/). 